\title{
THE FIRST MEXICIAN RECORD OF A COELACANTH (OSTEICHTHYES: SARCOPTERYGII) FROM THE TLAYUA QUARRIES NEAR TEPEXI DE RODRIGUEZ, PUEBLA, WITH A DISCUSSION ON THE IMPORTANCE OF THIS FOSSIL
}

ESPINOSA-ARRUBARRENA*, Luis, Instituto de Geología, Universidad Nacional Autónoma de México, Cd. Universitaria, Delegación Coyoacán, 04510, México, D.F.; APPLEGATE, Shelton P., Instituto de Geología, Universidad Nacional Autónoma de México, Cd. Universitaria, Delegación Coyoacán, 04510, México, D.F.; GONZÁLEZ-RODRÍGUEZ, Katia, Instituto de Geología, Universidad Nacional Autónoma de México, Cd. Universitaria, Delegación Coyoacán, 04510, México, D.F.

Recently, a coelacanth, the first to be known from Mexico, was discovered by Dr. Lance Grande in the unidentified fish section of the Tepexi collections of the Paleontological Museum of the Instituto de Geología, UNAM. The specimen consists of two slabs, that were collected in the locality 2432 , which is in the bottom part of the Alacranes Quarry and represents the central part of what is known as the Tlayúa Quarries.

This coelacanth is referrable to the genus Axelrodichthys described by Dr. John Maisey, from the Lower Cretaceous, Romualdo Member of the Santana Formation in Chapada do Araripe, Brazil. The specific relationship between the Tlayúa specimen and A. araripensis is at the present under study, though indications are that it is the same species. A number of morphological features not noted in the works of Maisey are discussed, as well as the biogeographical implications of this new find. 